\title{
Obtaining a Spreadable Cheese Sort with Additives of Bioactive Compounds
}

\author{
Mihaela Adriana TIŢA* \\ ${ }^{*}$ Department of Agricultural Sciences and Food, Faculty of Agricultural Sciences, Food Industry and \\ Environmental Protection, Lucian Blaga University of Sibiu \\ ${ }^{*}$ Corresponding author, e-mail: mihaela.tita@ulbsibiu.ro
}

Bulletin UASVM Animal Science and Biotechnologies 74(2)/ 2017

Print ISSN 1843-5262; Electronic ISSN 1843-536X

DOI:10.15835/buasvmcn-asb: 0005

\begin{abstract}
To conduct this study, a market survey was conducted in the form of a questionnaire to see what assortment of cheese and what ingredients bioactive compounds people want to consume. In order to find out what assortment of cheese and what ingredients with bioactive compounds people want to consume, a market survey was made in the form of a questionnaire. Taking into account the results of the survey,to process a melted cheese mix with the addition of dried tomatoes and basil. A technological scheme was developed for this cheese and sodium bicarbonate was used instead of melting and emulsifying salts to try to obtain a healthier product. The obtained product was analyzed for a period of 30 days from a sensory and physico-chemical. Physico-chemical and sensory properties of the obtained product were analyzed for a period of 30 days.
\end{abstract}

Keywords: bioactive compounds, cheese, ingredients

\section{INTRODUCTION}

Melted cheeses are a variety of assortments that differ in composition, sensory characteristics, shape, packaging and price. (Costin, 2003). The raw materials used to obtain the melted cheeses are very diverse, the technologist having to use the cheeses with the most suitable characteristics for the finished product. Often, by combining cheeses with different degree of maturation good results are achieved, because the young cheese contribute to the freshness of the taste and bring an acidity intake and matured cheese contribute to the characteristic flavor. (Georgescu et.al., 2005). The tomatoes, Solanum lycopersicum are rich in mineral substances and vitamins. They mainly contain vitamins B1, B2, B3, B6, B9, E and a large amount of vitamin $C$, but also contain one of the most powerful antioxidants - lycopene that stimulates the immune system, helping the body to fight against infections. (Popescu et al., 2013). The basil, Ocimum basilicum considered ", the king of spices" by many chefs and authors of gourmet books, is a plant that grows in all the regions of our country and it has an aromatic and specific flavor and taste. (Constantinescu et al., 1986)

\section{AIMS AND OBJECTIVES}

To carry out this study, we have done a market study in the form of a questionnaire to find out what assortment of cheese and what ingredients with bioactive compounds, people want to consume. Taking into account the results, an assortment of melted cheese with the addition of dried tomatoes and basil was decided to be produced.

\section{MATERIALS AND METHODS}

The recipe adopted has in composition matured cheese made from goat's milk, dried tomatoes, basil, butter, salt and instead of melting salts, sodium bicarbonate was used as a lifting agent. The goat milk comes from a private farm that feeds animals with organic food. To obtain a high-quality cheese, the milk, raw material, was subjected to microbial quality determination using the sample of reductase with methylene blue. This analysis confirmed the microbiological quality of 
this goat's milk. It followed the obtaining of cheese from goat milk without applying heat treatment. The obtained cheese was maturation for 60 hours until the cheese has reached the acidity of $285^{\circ} \mathrm{T}$. This acidity value is an optimal value for processing this type of cheese according to the ingredients we intended to use. After obtaining an optimal manufacturing recipe, the components were weighted and mixed, after which they were subjected to the melting operation and then packed in plastic boxes with a capacity of $0.100 \mathrm{~kg}$. The cheese with basil and dried tomatoes was analyzed over a period of 45 days, from 15 to 15 days, from a sensory point of view using the scoring method and physicochemical (Tita, 2002): determination of acidity by titration with $\mathrm{NaOH}$ in the presence of phenolphthalein, water activity with the Novasina device, sodium chloride content by argentometric method, dry substance with humidity analyser AND ML-50, pH determination with $\mathrm{pH}$-meter-Orion 2Star-Thermo Electron.

\section{RESULTS AND DISCUSSION}

Following the analyzes made for melted cheese with basil and dried tomatoes, at sensory analysis, figure 1, the tasters appreciated the sensory characteristics during the analyzed period. From physicochemical point of view it is noticed that the acidity, figure 2 shows a slow increase, in particular due to the composition of the tomatoes. The water activity, figure 3 , represent the result of processes that take place during the analyzed period and is

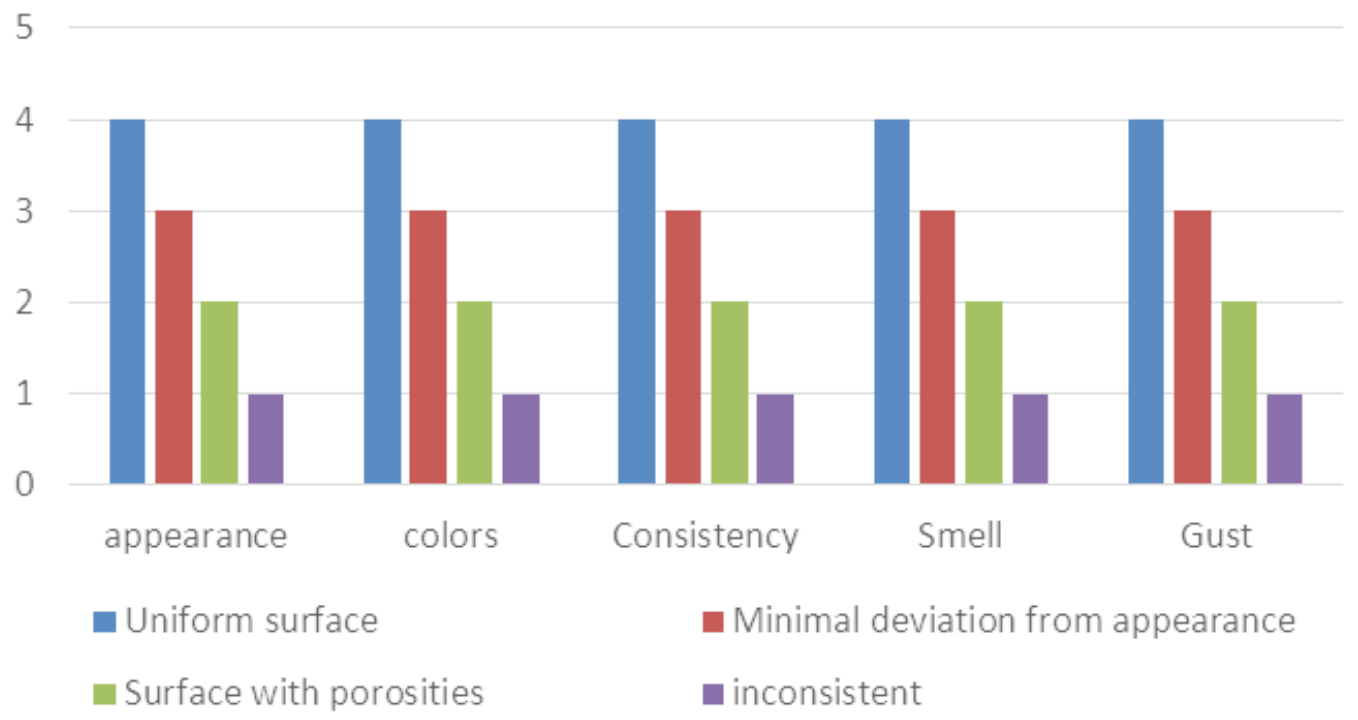

Fig. 1. Scoring scale for melted cheese with basil and dried tomatoes
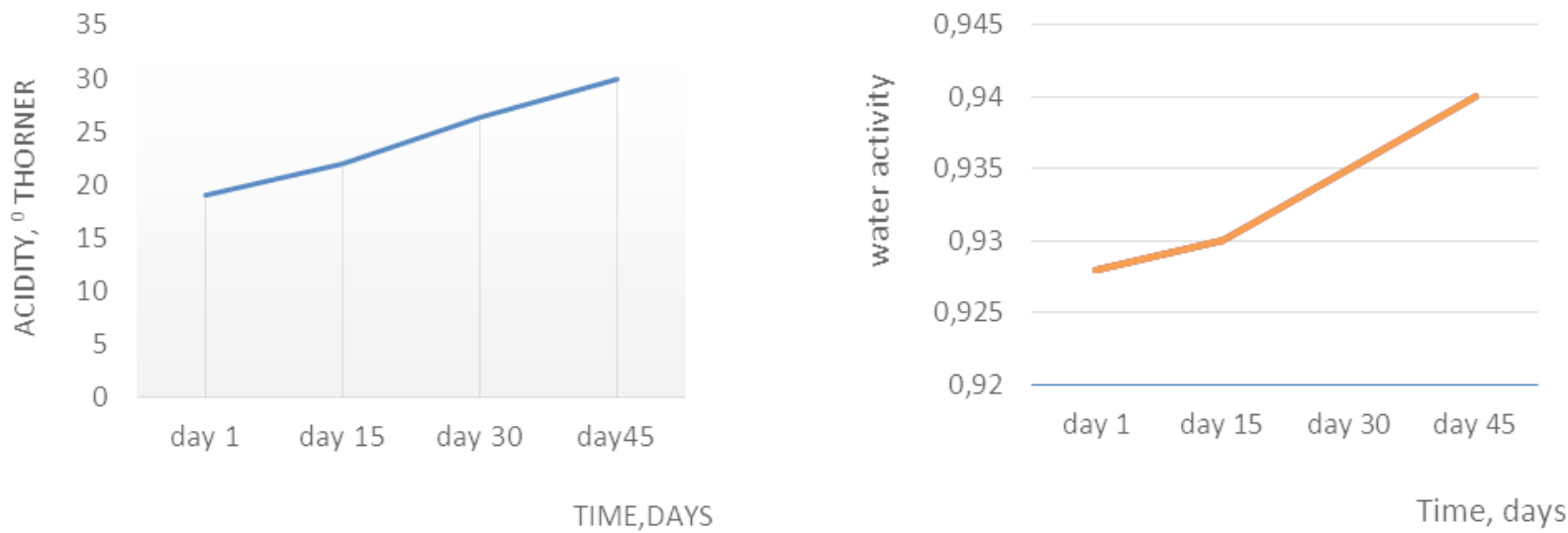

Fig. 2. Evolution of acidity

Fig. 3. Evolution of water activity 


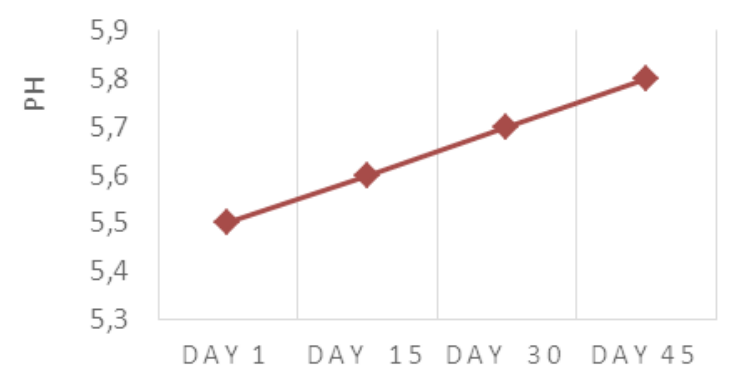

TIME, DAYS

Fig. 4. Evolution of $\mathrm{pH}$

observed an increase due to a balance between the components of the melted cheese and no present significant differences. From figure 4, it is noted that the $\mathrm{pH}$ is consistent with the increase of acidity in melted cheese during the analyzed period so that it falls within the values laid down in the quality standards for melted cheeses with additives. The salt content of the figure 5 shows no changes during the analyzed period because the melted cheese with dried tomatoes and basil was packed in plastic boxes that were closed with a lid which did not allow the product to contact with the air so as to be loss of moisture.

\section{CONCLUSION}

In the present research work, was demonstrated that this is an innovative technology, proof being the results obtained from sensory and physicochemical analysis. The tasters appreciated with high scores the sensory characteristics of the melted cheese with basil and dried tomatoes,

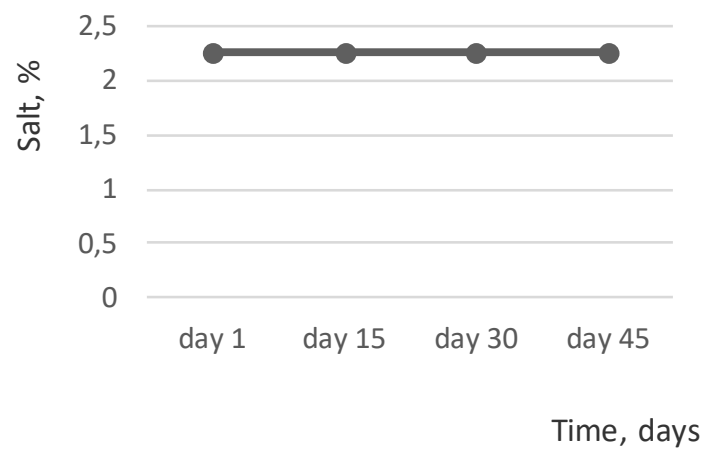

Fig. 5. Evolution of salt content

as well as the physicochemical characteristics analyzed showed a good evolution. Following the results, the studies will continue by determining the bioactive compounds from tomatoes, basil and the product obtained by adding this ingredients.

\section{REFERENCES}

1. Costin GM (2003). Știința și ingineria fabricării brânzeturilor, Editura Academică, Galaţi, p.435-443;

2. Georgescu Ghe, Banu C., Mărginean Gh., Păsat GhD, Dorin S, (2005). Cartea producatorului si procesatorului de lapte, vol.4, Cunoaşterea şi procesarea laptelui, Ed. Ceres, Bucureşti, p. 393-398;

3. Popescu V, Zăvoianu R (2013). Cultura tomatelor, ardeiului şi vinetelor, Editura Mast, p.18-20;

4. Constantinescu Gr, Haţieganu-Buruiana E (1986). Să ne cunoaştem plantele medicinale-proprieăţile lor terapeutice şi modul de folosire, Editura Medicală, București, p.56-57;

5. Tita MA (2002). Manualul de analiză şi controlul calitatii în industria laptelui, Editura Universităţii Lucian Blaga din Sibiu, p.271-278. 